\title{
INFEKSI SALURAN KEMIH PADA GERIATRI
}

\author{
Torayraju. $K$ \\ Fakultas Kedokteran Universitas Udayana \\ (kokeela_torayraju1107@yahoo.com)
}

\section{ABSTRAK}

Jumlah penderita infeksi saluran kemih (ISK) pada geriatri di Indonesia akan semakin meningkat dan menjadi penyebab kedua tersering setelah pneumonia. Pendekatan diagnosis dan terapi ISK pada geriatri memiliki kekhususan. Ada tidaknya gejala dan tanda spesifik serta bagaimana cara pengambilan spesimen turut berperan dalam diagnosis ISK pada geriatri. Faktor predisposisi penderita ISK pada geriatri meliputi diabetes melitus, gizi kurang, gangguan faal kognitif, depresi, gangguan status fungsional, prostatitis, riwayat operasi, dan prolaps vagina. Gejala dan tanda yang sering muncul adalah sindrom delirium, inkontinensia urin dan syncope yang diawali oleh penurunan nafsu makan. Strategi penatalaksanaan meliputi modalitas nonfarmakologik dan farmakologik.

Kata Kunci : infeksi saluran kemih (ISK), geriatri.

\begin{abstract}
Number of patients with urinary tract infection (UTI) in geriatrics in Indonesia will increase and become the second most common cause after pneumonia. Approach to the diagnosis and treatment of UTI in geriatrics have specificity. Presence or absence of specific signs and symptoms and how to get the specimen contribute to the diagnosis of UTI in geriatrics. Predisposing factors in geriatric patients with UTI include mellitus diabetic, malnutrition, impaired cognitive function, depression, impaired functional, prostatitis, surgical history, and vaginal prolapse. Symptoms and signs that often arises is the delirium syndrome, urinary incontinence and syncope were preceded by a decrease in appetite. Management strategies include nonpharmacologic and pharmacologic modalities.
\end{abstract}

Keyword : urinary tract infection (UTI), geriactric.

\section{PENDAHULUAN}

Jumlah penderita geriatri yang meningkat bisa menjadi beban jika tidak diantisipasi dengan bijak. Penyebab munculnya gejala yang dikeluhkan akibat infeksi yang tertinggi kedua setelah pneumonia pada kelompok populasi tersebut adalah infeksi saluran kemih (ISK). Di RSCM pernah dilaporkan kejadian ISK pada 104 penderita yang berhasil dikumpulkan selama periode enam bulan adalah $35,6 \%{ }^{3}$ Gejala dan tanda ISK pada penderita geriatri sering sulit dikenali sehingga pengobatannya sering terlambat. Pengobatan yang terlambat mempunyai konsekuensi besar pada penderita geriatri, antara lain iatrogenesis, menurunnya status fungsional pascarawat, sampai kematian yang tidak semestinya terjadi. Di sisi lain, berbagai upaya dapat dilakukan untuk mendeteksi secara dini ISK sehingga pengelolaannya bisa lebih baik. Pada awal ulasan ini sebaiknya diperhatikan bahwa terdapat perbedaan pengertian antara penderita usia lanjut dan penderita geriatri.

\section{KARAKTERISTIK}

Karakteristik penderita geriatri yang pertama, multipatologi yaitu pada satu penderita terdapat lebih dari satu penyakit yang umumnya bersifat kronik degeneratif. Kedua, menurunnya fungsi daya cadangan yang menyebabkan penderita geriatri sangat mudah mengalami syncope dalam kondisi gagal pulih (failure to thrive). Karakteristik kedua terjadi akibat penurunan fungsi berbagai organ atau sistem organ, yang walaupun normal untuk usianya namun telah menandakan menurunnya fungsi daya cadangan. Ketiga, berubahnya gejala dan tanda penyakit dari yang klasik misalnya, pada pneumonia tidak dijumpai gejala khas seperti batuk, demam, dan sesak melainkan syncope atau terdapat perubahan kesadaran. Keempat, terganggunya status fungsional penderita geriatri. Status fungsional adalah kemampuan seseorang untuk melakukan aktivitas hidup sehari-hari. Keadaan status fungsional menggambarkan kemampuan umum seseorang, sekaligus menggambarkan kondisi kesehatannya secara umum. Kelima, sering terdapat 
gangguan nutrisi, berupa gizi kurang atau gizi buruk. ${ }^{1,5,6,9}$

\section{FAKTOR PREDISPOSISI}

Perempuan usia lanjut tetap mempunyai risiko lebih tinggi daripada laki-laki untuk menderita ISK. Demikian pula kelompok usia lanjut yang tinggal di panti, biasanya lebih mudah menderita ISK daripada mereka yang masih mampu tinggal di tengah-tengah masyarakat. Mereka dengan status gizi kurang memiliki resiko ISK sebanyak 8-12 kali lebih tinggi dibandingkan mereka dengan status gizi normal. Gangguan fungsi kognitif seperti demensia (terutama demensia sedang sampai berat) akan mengakibatkan usaha perawatan diri sendiri terganggu. Seperti kemampuan untuk mandi dengan bersih, membersihkan daerah genitalia dengan seksama, tidak dapat dilakukan secara mandiri. Bisa jadi seorang penderita geriatri dengan demensia berat menjadi lupa mandi atau lupa membersihkan genitalia sesudah defekasi sehingga area perineum terpajan dengan bakteri lebih lama. Depresi yang juga sering terdapat pada penderita geriatri mempunyai gejala antara lain kehilangan minat, keengganan untuk merawat diri, termasuk membersihkan area genitalia. Keadaan tersebut menyebabkan meningkatnya kemungkinan ISK pada penderita geriatri dengan gangguan mood. Gangguan menurunnya minat dapat berdampak pada menurunnya asupan makan, sehingga status nutrisi menurun akibat menurunnya daya tahan tubuh. Defisiensi estrogen akan mengakibatkan daerah genitalia menjadi lebih kering sehingga lebih mudah terinfeksi. Selain itu, keasaman vagina juga dapat berkurang sehingga perlindungan umum pada daerah mukosa menjadi berkurang. Pengosongan kandung kemih yang tidak maksimal (kecepatan aliran air seni kurang dari $10 \mathrm{ml} /$ detik dan sisa air seni di kandung kemih lebih dari $100 \mathrm{ml} /$ detik) menyebabkan di kandung kemih selalu terdapat air seni yang merupakan media pertumbuhan kuman. Tindakan bedah dan prolaps vagina (dengan urethral kinking effect) juga sering mengakibatkan pengosongan kandung kemih tidak optimal. Menurunnya status fungsional pascastroke merupakan salah satu faktor risiko yang penting. Kemampuan gerak ekstremitas yang berkurang, ketidakseimbangan postural serta gangguan koordinasi mengakibatkan usia lanjut menjadi kurang seksama dalam melaksanakan aktivitas membersihkan diri sendiri, termasuk daerah genitalia. Perempuan usia lanjut dengan status fungsional yang lebih rendah akan mempunyai resiko 2,66 kali lebih tinggi untuk terjadinya ISK dibandingkan dengan perempuan usia lanjut yang lebih mandiri. Penderita dengan inkontinensia urin sebagai salah satu bentuk sindroma geriatri akan memerlukan ketrampilan dan keseksamaan yang memadai untuk menjamin daerah genitalia tetap kering dan tidak lembab. Prostatitis kronis merupakan faktor predisposisi tersering pada penderita laki-laki usia lanjut. Batu saluran kemih juga merupakan faktor resiko yang harus dipertimbangkan terutama jika terjadi ISK berulang.

\section{GEJALA}

Menurunnya nafsu makan hampir selalu menjadi gejala awal dari berbagai jenis infeksi pada geriatri termasuk penderita ISK. Penurunan nafsu makan tersebut sering dianggap sebagai suatu hal yang biasa pada warga usia lanjut sehingga keluarga tidak begitu mempermasalahkan. Perlu diwaspadai bahwa perubahan nafsu makan tidak saja berperan sebagai tanda awal adanya penyakit yang serius, namun juga merupakan kondisi yang menurunkan status gizi dan kekebalan seseorang, apalagi pada kelompok usia lanjut. ${ }^{4}$ Jika keadaan ini dibiarkan maka keadaan umum penderita akan semakin lemah dan penderita cenderung lebih banyak berbaring. Kondisi kelemahan tubuh akan menurunkan status fungsionalnya, sehingga penderita cenderung immobile. Kondisi tersebut mempunyai berbagai dampak yang sangat luas. Penurunan status fungsional yang berujung pada tirah baring lama sering mengakibatkan inkontinensia urin. Jika penderita menggunakan popok dan tidak sering diganti dengan yang bersih dan kering, maka daerah genitalia akan terus menerus menjadi area yang sangat baik untuk berkembangbiaknya bakteri penyebab ISK. Inkontinensia urin sendiri sering merupakan gejala ISK pada penderita geriatri. Kondisi lebih jauh adalah munculnya gejala perubahan kesadaran, delirium atau perubahan perilaku yang sering disalah-tafsirkan oleh keluarga dan tenaga kesehatan sebagai perubahan kepribadian atau stroke. Sindrom delirium yang sesungguhnya sedang terjadi itu, juga merupakan salah satu bentuk gejala yang muncul pada ISK. Penderita boleh jadi menjadi hipoaktif, hiperaktif, pola tidurnya berubah, atau fungsi kognitifnya menurun. ISK sering muncul dalam bentuk kegawatdaruratan akibat syncope, hal ini yang membawa penderita ke unit gawat darurat. Penderita mungkin masih mampu aktif dan kesadarannya kompos mentis namun tanpa alasan yang jelas mengalami syncope di rumah. Komplikasi dari jatuh merupakan topik bahasan sendiri yang memerlukan pendekatan khusus jika tenaga kesehatan berhadapan dengan penderita usia lanjut. Gejala klinis yang muncul seperti disuri dan polakisuri jarang ditemukan, walaupun bisa saja terjadi. Hal itu disebabkan karena kemampuan ekspresi penderita geriatri berbeda dengan penderita dewasa muda. Seperti telah dikemukakan, gangguan faal kognitif dan emosi sering mewarnai berbagai gejala penyakit pada penderita geriatri. Tanda-tanda seperti demam, nyeri tekan daerah suprapubik maupun sakit pinggang jarang sekali ditemukan. Kurva suhu basal harian (jika ada) yang dibandingkan dengan suhu tubuh saat terdapat ISK dapat dijadikan patokan dalam rangka membantu menegakkan diagnosis. 


\section{PENATALAKSANAAN}

Penatalaksanaan selalu terdiri atas dua ranah modalitas yakni yang nonfarmakologik dan farmakologik. Inkontinensia urin harus dievaluasi dengan cermat dan dikelola sesuai penyebabnya. Program nutrisi yang adekuat juga merupakan bagian dari terapi yang tidak terpisahkan. Tahap demi tahap asupan makanan dan cairan yang menuju optimal harus dikerjakan sesuai kebutuhan penderita. Jika penderita dirawat inap maka program aktivitas harus dirancang agar penderita tidak mengalami imobilisasi terlalu lama. ${ }^{3,5}$ Terapi farmakologik yang dianjurkan secara empiris disesuaikan dengan pola kuman yang ada di setiap tempat. Secara umum trimetoprimsulfametoksasol masih dapat dibenarkan. Golongan beta-laktam dan sefalosporin juga masih cukup efektif, namun akhir-akhir ini sudah mulai terdapat gejala negatif atau tekanan yang terlalu tinggi, dimana terdapat kesan negatif terhadap kesehatan dan pencapaian akademik seseorang pelajar. Stres yang bersifat konstan dan terus menerus mempengaruhi kerja kelenjar adrenal dan tiroid dalam memproduksi hormon. Adrenalin, tiroksin, dan kortisol sebagai hormon utama stres, yang akan naik jumlahnya dan berpengaruh secara signifikan pada sistem homeostasis. Adrenalin yang bekerja secara sinergis dengan sistem saraf simpatis berpengaruh terhadap kenaikan denyut jantung, dan tekanan darah. Tiroksin selain meningkatkan Basal Metabolism Rate (BMR), juga menaikkan denyut jantung dan frekuensi nafas. Namun, pemaparan stres yang ringan atau sementara tidak menyebabkan penyakit sistemik, hanya menyebabkan peningkatan tekanan darah sebagai proses homeostasis dan kecenderungan resistensi. Saat ini golongan kuinolon merupakan terapi pilihan secara empiris yang bisa diberikan kepada penderita baik yang berobat jalan maupun rawat inap. Lama pengobatan minimal tujuh hari. Pada keadaan yang lebih berat atau dengan penyulit sebaiknya diberikan selama 14 hari. Penderita geriatri laki-laki secara umum mendapat terapi antibiotik selama 14 hari. Karena penderita geriatri biasanya mempunyai komorbiditas yang multipel maka pemberian obat harus hati-hati dan mempertimbangkan prioritas pemecahan masalah. Pemberian obat ISK pada penderita geriatri mengacu kepada prinsip pemberian obat pada usia lanjut, umumnya dengan memperhitungkan kelarutan obat, perubahan komposisi tubuh, status nutrisi (kadar albumin), dan efek samping obat (mual, gangguan fungsi ginjal). Pada penderita rawat inap atau disertai penyulit, infeksi pada saluran kemih bagian atas, infeksi berulang, atau penderita dalam penggunaan kateter, harus dilakukan pemeriksaan untuk memantau faal ginjal secara berkala.

\section{KESIMPULAN}

Penderita geriatri mempunyai karakteristik yang berbeda dari penderita dewasa muda sehingga gejala dan tanda infeksi saluran kemih pada populasi ini berbeda. Sindrom delirium dan syncope merupakan gejala yang paling sering muncul yang menyebabkan penderita geriatri dibawa oleh keluarga ke unit gawat darurat sebuah rumah sakit. Perubahan dari suhu basal sehari-hari bisa menjadi petunjuk akan adanya infeksi termasuk ISK. Pemeriksaan urin lengkap dan biakan urin merupakan pemeriksaan standar yang dipakai untuk membantu menegakkan diagnosis. Untuk itu diperlukan teknik pengambilan sampel yang benar. Penatalaksanaan non-farmakologik dan farmakologik sama pentingnya dalam pengelolaan ISK pada geriatri.

\section{DAFTAR PUSTAKA}

1. Adelman, A.M. 2001. "Managing Chronic Illness". In M. Adelman AM, Daly MP. (Ed.). Twenty Common Probelms in Geriatrics (pp. 314). 1st ed. McGraw Hill, New York.

2. Nicolle, L.E. 2003. "Urinary Tract Infections in The Elderly". In Hazzard WR, Blass JP, Ettinger WH, Halter JF, Ouslander JG. (Ed.). Principles of Geriatric Medicine and Gerontology (pp.11071116). McGrawHill, New York.

3. Nikolaus, T., Specht-leible, N., Bach, M., Oster, P., Schlierf, G. 1999. “A randomized trial of comprehensive geriatric assessment and home intervention in the care of hospitalized patients". Age and ageing, 28. 543-550.

4. Richardson, J.P. 2001. "Infection in The Urinary Tract". In Adelman AM, Daly MP. (Ed.). Twenty Common Problems in Geriatrics (pp.349-55). McGraw-Hill, Singapore.

5. Semeraro, S.T.M. and Motta, M. 2001. "Effectiveness of geriatric evaluation and care". One-year results of a multicenter randomized clinical trial. Aging (Milano), 13(5). 395-404.

6. Supartondo. 2002. Pendekatan klinik pasien geriatri di rawat jalan dan rawat inap. Dalam: Abstrak Temu Ilmiah Geriatri 2002: Penatalaksanaan Pasien Geriatri/Usia Lanjut secara Terpadu dan Paripurna, Jakarta. PIP Bagian Ilmu Penyakit Dalam FKUI, Jakarta. 1821.

7. Timmons, MC. 2003. "Gynecologic and Urologic Problems of Older Women". In Cassel CK, Leipzig RM, Cohen HJ, Larson EB, Meier DE. (Ed.). Geriatric medicine: An Evidence Based Approach (pp.743-5). Springer Verlag, New York.

8. Wahyudi, ER. 2004. "Prevalensi infeksi saluran kemih dan sebaran faktor risiko pada pasien usia lanjut di RSCM" (pp.36). Departemen IImu Penyakit Dalam FKUI, Jakarta.

9. Williams, M.E. 1999. "The Approach To Managing The Elderly Patients". In Hazzard WR, Blass JP, Ettinger WH, Halter JF, Ouslander JG (Ed). Principles of Geriatric 
Medicine and Gerontology (pp.249-52). McGraw-Hill, New York.

10. Yoshikawa TT. 2003. "Infectious Diseases". In Cassel CK, Leipzig RM, Cohen HJ, Larson EB, Meler DE (Ed). Geriatric medicine: An evidence - based approach (pp.805-6). Springer-Verlag, New York. 